\title{
Profil Klinis, Laboratorium, dan Serologi Infeksi Virus Dengue pada Bayi
}

\author{
Rinang Mariko, * Sri Rezeki S. Hadinegoro** \\ *Bagian Ilmu Kesehatan Anak Fakultas Kedokteran Universitas Andalas/ RS M. Djamil, Padang \\ **Departemen Ilmu Kesehatan Anak Fakultas Kedokteran Universitas Indonesia/ RSUPN Cipto \\ Mangunkusumo Jakarta
}

\begin{abstract}
Latar belakang. Kejadian infeksi virus dengue (IVD) meningkat di Sumatera Barat pada beberapa tahun terakhir. Bahkan, terjadi pada anak usia kurang dari satu tahun. Bayi mempunyai karakteristik klinik yang unik dan tidak banyak penelitian mengenai hal ini di Indonesia.

Tujuan. Mengetahui profil klinis, laboratorium, dan serologi infeksi virus dengue pada bayi yang dirawat di RSUP Dr. M Djamil Padang dari tahun 2012-2014

Metode. Seri kasus menggunakan data rekam medik bayi yang dirawat di RSUP Dr M Djamil Padang dari 1 Januari 2012 sampai 31 Desember 2014. Data mencakup usia, jenis kelamin, hari demam saat diagnosis, gejala dan tanda klinis, serta laboratorium.

Hasil. Duabelas bayi dengan usia termuda 3 bulan dan usia terbanyak 5 bulan (5/12). Muntah merupakan gejala tambahan yang paling banyak ditemukan (9/12), diikuti oleh ptekie dan syok (6/12), serta batuk (5/12). Infeksi primer didapatkan pada $8 / 12$ bayi.

Kesimpulan: Rerata usia dan kelompok usia terbanyak 5 bulan. Muntah merupakan gejala yang banyak ditemui, diikuti, petekie, batuk dan syok sebagian besar merupakan infeksi primer.
\end{abstract}

Sari Pediatri 2015;16(6):441-6.

Kata kunci: bayi, infeksi virus dengue, profil klinis

I

nfeksi virus dengue dapat menyerang semua usia, termasuk bayi usia kurang dari 1 tahun. Insiden demam berdarah dengue pada bayi berbeda-beda menurut beberapa literature, secara umum $1 \%-5 \%$ dari semua populasi. ${ }^{1}$ Penelitian lain

\footnotetext{
Alamat korespondensi:

Dr. Rinang Mariko, SpA. RSUD Sungai Dareh. Jl. Lintas Sumatera KM I, Pulau Punjung, Dhamas Raya, Sumatera Barat. E-mail: rinang_mariko@ idai.or.id
}

di Thailand tahun 1990-1994 menemukan insiden sekitar $2 \% .^{2}$ Di Chennai India pada epidemi tahun 2001, dijumpai kasus DBD pada bayi 3,4\% dengan usia termuda 30 hari. ${ }^{3}$ Penelitian lain di Nikaragua mendapatkan insiden DBD pada bayi sekitar 6\% dari seluruh kasus infeksi dengue yang dirawat di rumah sakit selama tahun 1999-2001. ${ }^{4}$ Di Indonesia masih sedikit publikasi tentang DBD pada bayi. Husada $\mathrm{dkk}^{5}$, tahun 2010 mendapatkan insiden infeksi dengue pada bayi $4,7 \%$, dengan DBD 1,5\%, usia terbanyak 
7-8 bulan dan usia termuda 4 bulan. ${ }^{5}$ Mayetti ${ }^{6}$ pada tahun 2007 melaporkan angka kejadian DBD pada anak usia $<1$ tahun di Rumah Sakit M Djamil Padang 1,5\% pada tahun 2007.

Demam berdarah dengue (DBD) pada bayi berbeda dengan anak dan dewasa dalam hal patogenesis, gejala klinis yang tidak khas, tingkat keparahan dan angka kematian yang tinggi. ${ }^{2,4,7}$ Teori secondary heterologous infection (teori infeksi sekunder) yang banyak dianut tentang patogenesis DBD, tidak berlaku pada bayi. Sementara itu, teori ADE (antibody dependent enhancement) merupakan teori yang banyak dianut dan merupakan teori yang menjelaskan patogenesis DBD pada bayi. Menurut teori ADE, derajat penyakit berhubungan dengan antibodi yang disalurkan secara vertikal dari ibu ke bayi. Dengan kata lain, risiko infeksi dengue pada bayi terjadi apabila antibodi maternal mencapai kadar subneutralizing (kadar terendah). ${ }^{8-10}$ Secara umum, bayi mempunyai manifestasi klinis yang berbeda dengan anak ataupun dewasa, misalnya insiden trombositopenia, kebocoran plasma, serta syok lebih tinggi dan insiden perdarahan lebih sedikit. ${ }^{1,4,7}$ Angka kematian akibat infeksi virus dengue pada bayi 6\% lebih tinggi dibandingkan kematian akibat infeksi virus dengue secara keseluruhan. Angka kematian yang tinggi berhubungan dengan ketahanan vaskuler bayi yang rendah dibandingkan anak ataupun dewasa. Syok mudah terjadi dan juga berhubungan dengan keterlambatan diagnosis dan tata laksana akibat gejala klinis yang tidak spesifik.

Bayi dengan infeksi virus dengue primer mempunyai karakteristik unik dan lebih berpotensi lebih berat dan membahayakan jiwa dibandingkan kelompok usia yang lebih tua. Terjadi peningkatan kasus DD ataupun DBD di Padang pada tahun 2012-2014, tetapi jumlah kasus bayi sedikit. Tujuan penelitian ini untuk mengetahui profil klinis, laboratorium dan serologi infeksi virus dengue pada bayi yang dirawat di RSUP Dr. M Djamil Padang dari tahun 2012-2014.

\section{Metode}

Penelitian dilakukan pada seri infeksi dengue dengan data rekam medik pasien rawat inap di bangsal anak RSUP Dr. M Djamil Padang dari 1 Januari 2012 hingga 31 Desember 2014. Kriteria inklusi mencakup bayi yang berusia kurang dari 1 tahun, didiagnosis secara klinis dan laboratoris sebagai infeksi virus dengue (demam dengue dan demam berdarah dengue) menurut Pedoman Diagnosis WHO 1997. Hasil pemeriksaan serologis imunoglobulin $M$ dan $G$ memperkuat diagnosis. Data demografik dan klinis yang dianalisis adalah usia, jenis kelamin, hari demam saat diagnosis, suhu, demam, batuk, diare, muntah, kejang, hematemesis, melena, syok, petekie, penurunan kesadaran dan hepatomegali. Pemeriksaan darah lengkap dilakukan berseri, sedikitnya dua kali selama masa perawatan. Hemokonsentrasi sebesar minimal $20 \%$ dihitung ulang dengan membandingkan kadar hematokrit maksimum (saat trombosit mencapai titik terendah) dengan kadar hematokrit sebelum pasien dipulangkan. Kasus dibagi menurut kelompok demam dengue (DD), demam berdarah dengue (DBD) dan sindrom syok dengue (SSD) dan selanjutnya data dianalisis dengan menggunakan software SPSS versi 21.

\section{Hasil}

Terdapat 12 bayi yang menderita infeksi virus dengue dan memenuhi kriteria inklusi yang dirawat selama periode 2012-2014. Diagnosis ke-12 bayi terdiri atas DD 1, DBD I 1, DBD II 4, dan SSD 6 bayi. Distribusi usia, jenis kelamin, gejala klinis dan pemeriksaan laboratorium tertera pada Tabel 1.

Jumlah pasien DBD terbanyak pada usia 5 bulan (5/12), dengan usia termuda 3 bulan. Jumlah antara bayi laki-laki dan perempuan sama. Demam dialami oleh seluruh pasien yang diteliti. Muntah merupakan gejala tambahan yang paling banyak ditemukan (9/12), diikuti oleh ptekie dan syok (masing-masing 6/12), serta batuk (5/12).

Trombositopenia ditemukan pada semua bayi. Trombosit terendah yang ditemukan adalah $10.000 / \mu \mathrm{L}$ dan tertinggi $129.000 / \mu \mathrm{L}$. Dari 12 bayi, 9 mempunyai data serologis pada bayi dan ibu. Infeksi primer terdapat pada 8 dari 12 bayi dengan dominasi Ig M (Ig $\mathrm{G}$ negatif), sedangkan infeksi sekunder 4 bayi (Ig $M$ dan Ig $G$ positif) (Tabel 2).

\section{Pembahasan}

Usia termuda bayi yang terinfeksi virus dengue yang kami jumpai 3 bulan, terbanyak kelompok usia 5 bulan. Perbandingan antara laki-laki dan perempuan adalah 
Rinang Mariko dkk: Profil klinis, laboratorium, dan serologi infeksi virus dengue pada bayi

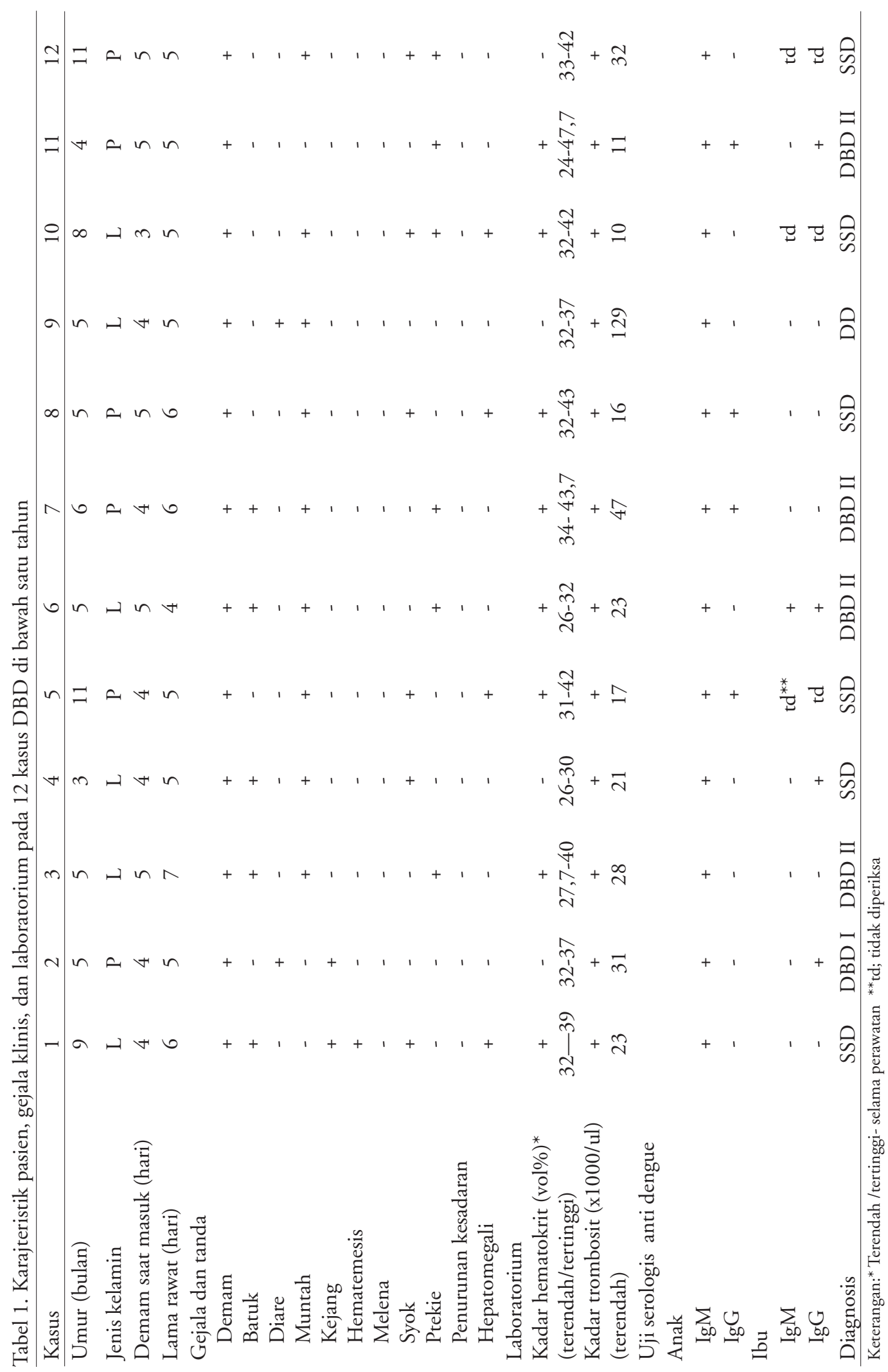

Sari Pediatri, Vol. 16, No. 6, April 2015 
Tabel 2. Infeksi dengue primer dan sekunder pada 12 kasus bayi.

\begin{tabular}{lc}
\hline Infeksi dengue & Jumlah $(\mathrm{n}=12)$ \\
\hline Infeksi primer & \\
Ig M (+) & 3 \\
Ig M (-) & 3 \\
Tidak diperiksa & 2 \\
Infeksi sekunder & 4 \\
\hline
\end{tabular}

1:1. Penelitian Hung ${ }^{4}$ dan Hammond $\mathrm{dkk}^{7}$ di Nicaragua menemukan frekuensi terbanyak pada usia 6-9 bulan. Studi di Chonburi, Thailand mendapatkan usia termuda 3 bulan dan terbanyak kelompok bayi DBD berusia 5-9 bulan. ${ }^{2}$ Beberapa penelitian di Vietnam menemukan usia terbanyak 4-10 bulan ${ }^{11,12}$ dengan perbandingan laki : perempuan 115:86, dan 9\% di antaranya kasus SSD. ${ }^{12,13}$ Penelitian lain juga di Vietnam mendapatkan dari 245 bayi dengan DBD, 63 (25,7\%) di antaranya mengalami SSD. Penelitian di Filipina selama dua tahun (2007-2009) menemukan manifestasi klinis pada bayi sangat bervariasi, insiden infeksi dengue asimtomatik pada bayi 103 per 1000 orang-tahun dan 6 kali lipat lebih tinggi dibandingkan infeksi dengue simtomatik. Kasus terbanyak asimtomatik pada bayi terjadi pada usia 8 bulan. ${ }^{1,14}$

Muntah, ptekie dan batuk merupakan gejala dan tanda klinik pada bayi yang terbanyak dialami selain demam. Hasil tersebut sesuai dengan data tahun 2000 di rumah sakit yang sama yang menjumpai muntah (60\%), batuk (55\%) dan diare (40\%) sebagai gejala klinik yang paling banyak didapatkan pada bayi dan kejadian SSD pada 50\% kasus. ${ }^{6}$

Penelitian yang telah dilakukan sebelumnya menunjukkan hasil yang bervariasi. Penelitian di Chonburi Thailand dari tahun 1995 sampai 1998 menemukan demam, pilek, dan hepatomegali sebagai gejala dan tanda yang banyak dijumpai pada DBD, sedangkan ruam didapatkan pada $26,7 \%$ kasus. Perdarahan terbanyak berupa perdarahan kulit/ petekie (58\%), dan SSD dialami oleh 32\% kasus bayi. ${ }^{2}$ Pada penelitian kami ditemukan hepatomegali pada 4 bayi dan 1 bayi dengan hematemesis. Penelitian lain pada periode 2003-2005 di Petchaburi Thailand menjumpai 14 bayi DBD, hepatomegali ditemukan pada seluruh kasus sementara petekie hanya dijumpai pada satu bayi. ${ }^{16}$ Studi di Vietnam oleh Hung $\mathrm{dkk}^{7}$ menemukan bahwa demam tinggi, petekie, dan hepatomegali adalah temuan klinis tersering pada bayi dengan DBD. Pada penelitian tersebut SSD dialami oleh 20,5\% bayi DBD.

Di Chennai, demam, pembesaran hati, dan ruam berturut-turut dijumpai pada $100 \%$, 93,1\%, dan $55,2 \%$ bayi infeksi dengue. ${ }^{3}$ Studi komunitas di Filipina, ${ }^{14}$ mendapatkan kejang demam, ruam makular, petekie, dan trombositopenia sebagai gambaran klinik yang berhubungan dengan DBD pada bayi. Secara umum, bayi mempunyai manifestasi klinis yang berbeda dengan anak yang lebih tua, dengan frekuensi trombositopenia, kebocoran plasma, kejadian syok lebih banyak, dan lebih sedikit perdarahan., ${ }^{4,7} \mathrm{Di}$ Vietnam, hepatomegali dijumpai 93\% dan petekie $99 \%$ namun perdarahan lain yang nyata hanya didapati pada 5\% kasus. Di Chennai hampir semua bayi mengalami trombositopenia. ${ }^{3}$ Pada penelitian ini, trombositopenia didapatkan pada seluruh bayi dengan DBD dibandingkan dengan 79\% di Nicaragua, dan hampir $100 \%$ di Chennai, 50\% di antaranya mengalami petekie, dan tidak ditemukan kasus yang mengalami melena. Di Nicaragua, bayi yang mengalami perdarahan eksternal dan ruam dijumpai pada lebih dari $50 \%$ bayi. ${ }^{17} \mathrm{Di}$ Chonburi dilaporkan 95\% kasus DBD mengalami trombositopenia. ${ }^{2}$ Ruam konvalesen ternyata dijumpai hanya pada 1 dari 41 (2\%) dengan infeksi dengue primer di Filipina, ${ }^{14}$ tetapi angka di RS Queen Sirikit Bangkok mencapai 24\%. ${ }^{18}$ Gejala dan tanda bayi dengan infeksi dengue serupa dengan penyakit demam akut non dengue lain.

Pada penelitian kami, 67\% bayi merupakan infeksi primer. Penelitian Witayathawarnong $\mathrm{dkk}^{16}$ menemukan 92,8\% kasus infeksi pada bayi merupakan infeksi primer. Demikian juga dengan Libraty $\mathrm{dkk}^{8}$ di Filipina ${ }^{8}$ menemukan 59 dari 60 bayi mengalami infeksi primer, dan penelitian Husada di Surabaya mendapatkan 14 dari 15 bayi yang memiliki data serologis menunjukkan infeksi primer. Penelitian Halstead dkk ${ }^{1}$ di Thailand, Vietnam, Myammar dan Indonesia mendapatkan infeksi dengue primer pada bayi umumnya disebabkan virus Den-2 dan antibodi maternal yang didapatkan adalah antibodi terhadap virus Den-4.

Pada penelitian Hung dkk, $93,5 \%$ bayi menunjukkan gambaran infeksi primer. Penelitian di dua rumah sakit di Vietnam menjumpai proporsi infeksi primer hampir $100 \%$ dan $80 \%$ di antaranya menjadi DBD/DSS. ${ }^{9}$ Di Chonburi Thailand, 95\% kasus merupakan infeksi primer, ${ }^{2}$ sedangkan penelitian Petchaburi menemukan 92,8\% kasus dengan infeksi 
primer. Jadi, beberapa studi di Thailand dan Vietnam menunjukkan proporsi infeksi primer 90\%-100\%. , $^{2,16,20}$ Dilaporkan 23 dari 24 kasus di India tahun 2001 menunjukkan respon IgM yang dominan. ${ }^{3}$ Beberapa penelitian juga menyebutkan bahwa DBD/SSD pada bayi umumnya timbul pada infeksi dengue primer dengan hipotesis bahwa derajat penyakit berhubungan dengan antibodi yang disalurkan secara vertikal dari ibunya. ${ }^{1,15,16,19}$ Hasil yang agak berbeda dilaporkan dari Nicaragua, dijumpai $58 \%$ bayi usia 1 tahun mengalami infeksi sekunder. ${ }^{4}$

Umumnya, DBD pada bayi merupakan infeksi primer, dengan ibu yang mempunyai riwayat pernah terinfeksi virus dengue. Teori infection enhancing antibody merupakan teori yang dapat menjelaskan keadaan tersebut dan sampai sekarang banyak dianut. Menurut teori ADE, Ig-G anti dengue yang terbentuk pada ibu dapat ditransmisikan ke bayi melalui sawar plasenta. Antibodi (Ig-G) maternal ini dapat menetralisasi infeksi dengue dengan serotipe yang sama yang menginfeksi ibu, artinya apabila bayi terinfeksi virus dengue dengan serotipe yang sama dengan serotipe yang pernah menyerang ibu maka infeksi tersebut dapat dinetralisasi. Namun sebaliknya, antibodi maternal tersebut bersifat non neutralizing antibody terhadap serotipe yang berbeda (heterolog). Apabila bayi mengalami infeksi primer dengan serotipe yang berbeda, maka antibodi maternal yang telah ada akan berikatan dengan virus dengue tersebut dan membentuk kompleks antigen antibodi yang akan berikatan dengan Fc reseptor pada membran sel terutama makrofag. Oleh karena antibodi heterolog terhadap virus, maka virus tidak akan dinetralisasi dan akan bebas melakukan replikasi dalam sel makrofag sehingga terjadi proses enhanching (penggandaan infeksi). Infeksi dan aktivasi makrofag akan menyebabkan pelepasan mediator inflamasi seperti IL-1, IL-6, dan TNF-alpha yang akan memengaruhi endotel pembuluh darah sehingga terjadi kebocoran plasma dan perdarahan. ${ }^{8,9,21-24}$

Antibodi maternal yang hilang berhubungan dengan usia puncak kejadian infeksi dengue pada bayi. Risiko DBD bayi muncul apabila antibodi maternal mencapai kadar subneutralizing. Antibodi maternal akan melindungi bayi dari infeksi virus dengue, tetapi selanjutnya setelah Ig-G dikatabolisasi sehingga kadarnya terus menerus menurun, risiko mengalami DBD/DSS meningkat. Hal tersebut terlihat pada penelitian kami, 5/6 kasus SSD terjadi pada usia lebih dari 5 bulan.

\section{Kesimpulan}

Demam berdarah dengue pada bayi berbeda dengan anak dan dewasa, gejala klinis yang tidak khas. Derajat penyakit berhubungan usia kurang dari 5 bulan dengan antibodi yang ditransmisikan secara vertikal dari ibunya. Kejadian infeksi dengue pada bayi di RS Dr M Djamil rerata usia 5 bulan. Gejala dan tanda klinis, muntah lebih banyak ditemukan diikuti dengan syok, petekie dan batuk. Pada hasil laboratorium ditemukan trombositopenia pada semua kasus DBD/DSS dan hampir semua kasus terjadi peningkatan hematokrit $>20 \%$. Sebagian besar kasus adalah infeksi dengue primer.

\section{Daftar pustaka}

1. Halstead SB, Lan NT, Myint TT. Dengue hemorrhagic fever in infants: research opportunities ignored. Emerg Infect Dis 2002;8:1474-9.

2. Hongsiriwon S. Dengue hemorrhagic fever in infants. Southeast As J Trop Med Publ Health 2002;33:49-55.

3. Kabilan LL, Balasubramaniam S, Keshava SM. Dengue disease spectrum among infants in the 2001 dengue epidemic in Chennai, Tamil Nadu, India. J Clin Microbiol 2003;41:3919-21.

4. Hammond SN, Balmaseda A, Perez L, Tellez Y, Sabario SA, Mercado JC, dkk. Differences in dengue severity in infants, children, and adults in a 3-year hospital based study in Nicaragua. Am J Trop Med Hyg 2005;73: 1063 70.

5. Husada D, Rani C, Puspitasari D, Darmawandowo W, Basuki PS, Ismoedijanto. Profil klinik infeksi virus dengue pada bayi di Surabaya. Sari Pediatri 2012;13:43744.

6. Mayetti. Hubungan gambaran klinis dan laboratorium sebagai faktor resiko syok pada demam berdarah dengue. Sari pediatric 2010;11:367-73.

7. Hung NT, Lei HY, Lan NT, Lin YS, Huang KJ, Lien LB, dkk. Dengue hemorrhagic fever in infants: a study of clinical and cytokine profiles. J Infect Dis. 2004;189:22132 .

8. Libraty DH, Acosta LP, Tallo V, Mercado ES, Bautista A, Potts JA, dkk. A prospective nested case-control study of dengue in infants: rethinking and refining the antibody-dependent enhancement dengue hemorrhagic fever model. PLoS Med 2009; 6:e1000171.

9. Jain A, Chaturvedi UC. Dengue in infant. FEMS Immunol Med Microbiol 2010;119-30. 
10. Sutaryo. Perkembangan patogenesis demam berdarah dengue. Dalam: Hadinegoro SR, Satari HI, penyunting. Naskah lengkap; Pelatihan bagi pelatih dokter spesialis anak dan dokter spesialis penyakit dalam dalam tatalaksanan kasus DBD. Edisi ke-3. Jakarta: Fakultas Kedokteran Universitas Indonesia; 2004.h. 32-43

11. Soegijanto S. Patogenesa dan perubahan patofisiologi infeksi virus dengue. Diakses 10 Februari 2013. Diunduh dari: http://old.pediatric.com/buletin/200602208ma2gi-buletin.pdf

12. Chau TNB, Quyen NTH, Tuan NM. Dengue in Vietnamese infants - results of infection-enhancement assays correlate with age-related disease epidemiology, and cellular immune responses correlate with disease severity. J Infect Dis 2008;198:516-24

13. Chau TNB, Anders KL, Hung NT. Clinical and virological features of dengue in Vietnamese infants. PLoS Negl Trop Dis 2010;4: e657

14. Capeding R, Brion J, Caponpon MM, Gibbons RV, Jarman RG, yoon IK, dkk. The incidence, characteristics, and presentation of dengue virus infections during infancy. Am J Trop Med Hyg 2010;82:330-6.

15. Kliks SC, Nimmanitya S, Nisalak A, Burke DS. Evidence that maternal dengue antibodies are important in the development of dengue hemorrhagic fever in infants. Am J Trop Med Hyg 1988; 38: 411-9

16. Witayathawornwong P. Dengue hemorrhagic fever among infants in Petchabun Province, Thailand: 20032005. 2006;30:35-41.

17. Soedarmo SP. Infeksi virus dengue. Dalam: Soedarmo SP, Garna H, Hadinegoro SR, Satari HI, penyunting. Buku ajar infeksi dan pediatri tropis. Edisi ke-2. Jakarta: Badan Penerbit FKUI; 2008.h.155-81.
18. Hadinegoro SR. Kesenjangan dalam diagnosis dan tatalaksana demam berdarah dengue. Dalam Current management of pediatrics problem. Pendidikan Kedokteran Berkelanjutan Ilmu Kesehatan Anak XLVI, Jakarta 5-6 September 2004.

19. Pancharoen C, Mekmullica J, Thisyakorn U. Primary dengue infection: what are the clinical imadistictions from secondary infection?. J Trop Med. 2001;32:476-80

20. Rizal. Kebocoran plasma pada demam berdarah dengue. Cermin Dunia Kedok 2011;38:92-6.

21. Hidayah N, Darmowandowo W, Ismoedijanto, Soegijanto S. Dengue hemorrhagic fever in infant (clinical aspects, immunological responses related to clinical degrees, abstrak). Dalam: Program and Abstracts of the 1 st International Conference on Dengue/Dengue Hemorrhagic Fever (Chiang Mai, Thailand). Geneva: World Health Organization; 2000: 11

22. Chen K, Pohan HT, Sinto R. Diagnosis dan terapi cairan pada demam berdarah dengue. Medicinus 2009 ;22:37.

23. Hung TN, Lan TN, Lei HY, Lin YH, Lien LB, Huang $\mathrm{KJ}$, dkk. Volume replacement in infant with dengue hemorrhagic fever/dengue shock syndrome. Am J Trop Med 2006;74: 684-91.

24. Pengsaa K, Luxemburger C, Sabchareon A, Limkittul K, Yoksan S, Chambonneau L, dkk. Dengue virus infections in the first 2 years of life and the kinetics of transplacentally transferred dengue neutralizing antibodies in Thai children. JID 2006;194:1570-6.

25. Simmons PC, Chau TN, Thuy TT, Tuan NM, Hoang DM, Thien NT, dkk. Maternal antibody and viral factor in the pathogenesis of dengue virus in infant. JID 2007;196:416-24. 


\section{Daftar index penulis Majalah Sari Pediatri Volume 16 tahun 2014-2015}

A
Abdul Latief
Ackni Hartati
Adhitya Putra Pratama
Adi Utomo Suardi
Adrieanta
Afitasari
Agnes Rengga Indrati
Agung Triono
Agus Priyatno
Agustinus William
Albert Daniel Solang
Alex Chairulfatah
Alvi Lavina
Amalia Setyati
Amelia Harsanti
Amrin Alkamar
Andani Eka Putra
Anggraini Alam
Anidar
Anindita Soetadji
Anisah M. Saleh
Antonius Pudjiadi

Aris Primadi Arum Kusumaningtias Arwin AP Akib

Aryono Hendarto Asep Aziz Asopari Asri Purwanti
Sari Pediatri2014;16(4):271-7. Sari Pediatri 2014;16(4):254-9. Sari Pediatri 2014;16(4):236-40. Sari Pediatri 2014;16(3):215-20 Sari Pediatri 2014;16(3):195-200 Sari Pediatri 2014;16(3):157-60 Sari Pediatri 2015;16(5):325-9 Sari Pediatri 2014;16(3):183-8 Sari Pediatri 2015;16(5):315-8 Sari Pediatri2014;16(4):229-35. Sari Pediatri 2014;16(1):53-6. Sari Pediatri 2015;16(5):347-50 Sari Pediatri 2014;16(4):248-53 Sari Pediatri 2014;16(4):221-8 Sari Pediatri 2014;16(4):241-7. Sari Pediatri 2014;16(4):236-40. Sari Pediatri 2014;16(3):157-60 Sari Pediatri 2015;16(6):434-40 Sari Pediatri 2015;16(6):409-15 Sari Pediatri 2015;16(6):391-6 Sari Pediatri2014;16(3):178-82 Sari Pediatri 2014;16(2):121-7 Sari Pediatri 2014;16(2):121-7 Sari Pediatri 2015;16(5):347-50 Sari Pediatri 2015;16(5):351-5 Sari Pediatri 2014;16(3):189-94 Sari Pediatri 2015;16(6):385-90 Sari Pediatri 2014;16(4):292-8. Sari Pediatri2014;16(4):271-7. Sari Pediatri 2014;16(4):236-40. Sari Pediatri 2014;16(3):215-20 Sari Pediatri 2014;16(3):195-200 Sari Pediatri 2014;16(3):157-60 Sari Pediatri 2015;16(6):421-6 Sari Pediatri 2015;16(5):337-41 Sari Pediatri 2014;16(2):128-35. Sari Pediatri 2014;16(3):149-56 Sari Pediatri 2014;16(1):22-8. Sari Pediatri 2014;16(1):57-63. Sari Pediatri 2014;16(4):284-91.
Azwar Aruf

B

Badriul Hegar Syarif Bakhtiar

Bambang

Bambang Satoto

Bambang Tridjadja

Budi Setiabudiawan

Budi-Hartawan I Nym

C

Camellia Nucifera,

Cece Alfalah

Cissy B Kartasasmita

Cissy Sudjana Prawira Citra Fitri Agustina Cut Fera Rachmawati Cynthia Utami

D

Dalima AW Astrawinata Damaris Pali

Damayanti Rusli Sjarif

Dana Sumanti

Dany Hilmanto

Darfioes Basir

Darmawan B Setyanto

Dasril Daud

David Kaunang

Dede Lia Marlia,

Desti Handayani

Dewi Kartika Turbawaty

Diana Mariana Damanik

Diana Rosifah

Dida A Gurnida
Sari Pediatri 2014;16(1):97-102 Sari Pediatri 2014;16(2):91-6.

Sari Pediatri 2014;16(4):292-8. Sari Pediatri 2015;16(5):351-5 Sari Pediatri 2014;16(1):97-102 Sari Pediatri 2015;16(5):337-41 Sari Pediatri 2015;16(5):356-64 Sari Pediatri 2015;16(6):409-15 Sari Pediatri 2014;16(1):57-63. Sari Pediatri 2015;16(5):342-6 Sari Pediatri 2014;16(2):141-6

Sari Pediatri 2015;16(6):379-84 Sari Pediatri 2015;16(6):416-20 Sari Pediatri 2014;16(2):110-14. Sari Pediatri2014;16(3):210-4 Sari Pediatri 2014;16(1):47-52. Sari Pediatri 2014;16(3):173-7 Sari Pediatri 2014;16(2):86-90. Sari Pediatri 2014;16(2):103-9.

Sari Pediatri 2014;16(1):35-40. Sari Pediatri 2015;16(5):319-24 Sari Pediatri 2015;16(5):356-64 Sari Pediatri 2015;16(6):385-90 Sari Pediatri 2014;16(3):167-72 Sari Pediatri 2015;16(5):315-8 Sari Pediatri 2014;16(4):260-5. Sari Pediatri 2014;16(2):136-42. Sari Pediatri 2014;16(3):161-6 Sari Pediatri 2015;16(5):319-24 Sari Pediatri 2015;16(5):299-306 Sari Pediatri 2015;16(5):307-14 Sari Pediatri 2015;16(5):330-6 Sari Pediatri 2015;16(6):391-6 Sari Pediatri 2014;16(3):167-72 Sari Pediatri 2014;16(3):167-72 
Dwi Prasetyo

Dwi Putro Widodo

Dzulfikar DLH

\section{E}

Eddy Supriyadi

Edi Dharmana

Edwin Tohaga

Eki Rakhmah Zakiyyah

Elisabeth Siti Herini

Elvi Suryati

Elza Noviani

Endah Purnawati

Endang Windiastuti

Erna Mutiara

Ery Olivianto

\section{F}

Finny F Yani

Finny Fitry Yani

G

Gustina Lubis

\section{H}

Hafni Bachtiar

Hartono Gunardi

Heda Melinda Nataprawira

Hendra Salim

Hermawan

Hesti Kartika Sari

Hikari Ambara Sjakti

Hindra Irawan Satari

HMS Chandra K

\section{I}

I Putu Ardika Yuda

I Wayan Gustawan

Ida Parwati

Idham Amir

Ihat Sugianti

Ika Widyawati

Imran

Indria L. Gamayanti

Innike

Irene Yuniar

Ivena Susanti
Sari Pediatri 2014;16(2):110-14.

Sari Pediatri 2014;16(1):1-4

Sari Pediatri 2014;16(1):57-63.

Sari Pediatri 2015;16(5):342-6

Sari Pediatri 2014;16(2):103-9.

Sari Pediatri 2015;16(6):409-15

Sari Pediatri 2015;16(5):325-9

Sari Pediatri 2014;16(3):183-8

Sari Pediatri 2014;16(2):79-85.

Sari Pediatri 2014;16(1):29-34

Sari Pediatri 2014;16(2):110-14.

Sari Pediatri 2014;16(4):248-53

Sari Pediatri 2014;16(4):221-8

Sari Pediatri 2015;16(5):342-6

Sari Pediatri 2015;16(5):315-8

Sari Pediatri2014;16(4):229-35.

Sari Pediatri 2014;16(1):53-6.

Sari Pediatri 2015;16(6):379-84

Sari Pediatri 2015;16(6):416-20

Sari Pediatri 2014;16(4):260-5.

Sari Pediatri 2015;16(6):416-20

Sari Pediatri 2014;16(4):278-83 Sari Pediatri 2014;16(4):260-5.

Sari Pediatri 2015;16(5):356-64

Sari Pediatri 2014;16(1):11-6.

Sari Pediatri 2014;16(2):141-6

Sari Pediatri 2015;16(6):421-6

Sari Pediatri 2015;16(6):397-402

Sari Pediatri 2014;16(3):149-56

Sari Pediatri 2014;16(1):35-40.

Sari Pediatri 2015;16(6):379-84

Sari Pediatri 2014;16(2):115-20 Sari Pediatri 2014;16(1):35-40. Sari Pediatri 2015;16(5):347-50 Sari Pediatri 2014;16(1):35-40.

Sari Pediatri 2014;16(2):128-35.

Sari Pediatri 2014;16(3):173-7

Sari Pediatri 2015;16(5):351-5

Sari Pediatri 2014;16(4):266-70.

Sari Pediatri 2014;16(4):284-91.

Sari Pediatri 2014;16(4):254-9.

Sari Pediatri 2014;16(3):201-9
J

Jeanette I.Ch.Manoppo Sari Pediatri 2015;16(5):319-24

Johannes H. Saing Sari Pediatri 2015;16(6):375-8.

Jose RL Batubara

Sari Pediatri 2014;16(3):201-9

\section{$\mathbf{K}$}

Kadek Hartini

Kamilah Budhi

Kristin Handojo

Kusnandi Rusmil

$\mathbf{L}$

Lelani Reniarti

Lita Farlina

Luh Karunia Wahyuni

Sari Pediatri 2014;16(1):41-6. Sari Pediatri 2014;16(1):29-34

Sari Pediatri 2014;16(3):149-56

Sari Pediatri2014;16(3):178-82

Sari Pediatri 2015;16(6):434-40

Sari Pediatri2014;16(3):210-4

Sari Pediatri 2014;16(1):1-4

Sari Pediatri 2015;16(6):427-33

Sari Pediatri 2014;16(4):260-5.

Sari Pediatri 2014;16(1):22-8.

\section{M}

M. Supriatna TS Sari Pediatri 2014;16(1):97-102

M.Sholeh Kosim Sari Pediatri 2014;16(3):189-94

Magdalena E Sahetapy Sari Pediatri 2014;16(3):157-60

Mardjanis Said Sari Pediatri 2014;16(2):103-9.

Maria Mexitalia Sari Pediatri 2015;16(6):397-402

Marte Robiul Sani Sari Pediatri2014;16(3):210-4

Martina Wiwie Setiawan Nasrun

Mayetti
Megariani
Mei Neni Sitaresmi
Meida Erimarisya
Meida Tanukusumah,
Mercy Amelia
MMDEAH Hapsari
Moh. Supriatna

Sari Pediatri 2014;16(3):173-7

Sari Pediatri 2014;16(4):278-83

Sari Pediatri 2014;16(2):121-7

Sari Pediatri 2014;16(2):91-6.

Sari Pediatri 2014;16(1):11-6.

Sari Pediatri 2015;16(5):365-74

Sari Pediatri 2014;16(1):1-4

Sari Pediatri 2015;16(5):337-41

Sari Pediatri2014;16(4):271-7.

Sari Pediatri 2014;16(4):236-40.

Sari Pediatri 2014;16(3):215-20

Sari Pediatri 2014;16(3):157-60

Muhammad Ali

Mulyadi M. Djer

Munar Lubis

Sari Pediatri 2014;16(2):86-90.

Sari Pediatri 2014;16(2):71-8.

Sari Pediatri 2015;16(6):375-8.

Murti Andriastuti Sari Pediatri 2014;16(1):64-70.

N

Nadirah Rasyid Ridha Sari Pediatri 2014;16(3):161-6

Nadjwa Zamalek Dalimoenthe Sari Pediatri 2015;16(5):330-6

Najib Advani Sari Pediatri 2015;16(5):299-306

Sari Pediatri 2014;16(3):201-9

Nanan Sekarwana

Sari Pediatri2014;16(3):178-82

Sari Pediatri 2015;16(5):325-9

Sari Pediatri 2014;16(1):11-6. 
Nanik Tri Mulyani

Nastiti Kaswandani

Neti Nurani

Nevita

Nia Kurniati

Noor Wijayahadi

Novie Amelia C

Nur I Lipoeto

Nur M. Artha

Nurlina Kumala Sari

Nurmiati Amir

Nurul Iman Nilam Sari

$\mathbf{P}$

Piprim B. Yanuarso

Pramita G. Dwipoerwantoro, Sari Pediatri 2015;16(5):299-306

Primo Parmato Sari Pediatri 2014;16(1):22-8.

Pudjiastuti Sari Pediatri2014;16(4):271-7.

\section{$\mathbf{R}$}

Reggy Harapan Baringin Silalahi Sari Pediatri 2014;16(2):79-85.

Retno Sutomo

Ridha Kurnia Tejasari

Rina Amalia C. Saragih,

Rina Triasih

Rinang Mariko

Rini Purnamasari

Rininta Mardiani

Rismarini

Roni Naning

S

Setyo Handryastuti

Siti Aizah Lawang

Sjarif Hidajat Effendi

Soedjatmiko

Soetjiningsih
Sari Pediatri 2014;16(4):236-40.

Sari Pediatri 2014;16(3):215-20

Sari Pediatri 2014;16(3):157-60

Sari Pediatri 2015;16(6):385-90

Pediatri 2014:16(2):136-42.

Sari Pediatri 2014;16(1):64-70.

Sari Pediatri 2015;16(5):356-64

Sari Pediatri 2014;16(1):41-6.

Sari Pediatri 2015;16(5):365-74

Sari Pediatri 2014;16(4):221-8

Sari Pediatri 2015;16(5):365-74

Sari Pediatri 2015;16(6):416-20

Sari Pediatri 2014;16(4):266-70.

Sari Pediatri 2015;16(5):356-64

Sari Pediatri 2014;16(4):266-70.

Sari Pediatri 2014;16(1):5-10.

Sari Pediatri 2015;16(6):391-6

Sari Pediatri 2015;16(6):427-33

Sari Pediatri 2015;16(6):375-8.

Sari Pediatri 2014;16(1):5-10.

Sari Pediatri 2014;16(2):121-7

Sari Pediatri 2015;16(6):441-6

Sari Pediatri 2014;16(4):241-7.

Sari Pediatri 2015;16(5):307-14

Sari Pediatri 2014;16(1):17-21

Sari Pediatri 2015;16(5):307-14

Sari Pediatri 2014;16(2):91-6.

Sari Pediatri2014;16(4):229-35. Sari Pediatri 2014;16(3):195-200 Sari Pediatri 2015;16(6):427-33 Sari Pediatri 2014;16(2):128-35. Sari Pediatri 2014;16(1):41-6.
Sofni Sarmen

Sri Endah Rahayuningsih

Sri Martuti

Sri Rezeki S. Hadinegoro

Sri Sofyani

Sri Utami

Suci Fitrianti

Sudung O Pardede

Sukman Tulus Putra

Sunartini

Suparyatha IB

Surastusi Nurdadi

Swanty Chunnaedy

Syarif Husin

Syilvia Jiero

T

Tena Rosmiati Iskandar,

Tetty Yuniati

Theodorus

Tjhin Wiguna

Tristia Rinanda

W

Wahyuni Indawati

Widodo Tirto

Wisnu Barlianto

Wistiani

Wiwin Winiar

Y

Yanti

Yetty M Nency

Yoga Devaera

Yudianita Kesuma

Yulia Dasmayanti

Yulia Iriani

Yusrina Istanti
Sari Pediatri 2014;16(4):278-83

Sari Pediatri 2014;16(1):47-52.

Sari Pediatri 2015;16(6):403-8

Sari Pediatri 2014;16(3):157-60

Sari Pediatri2014;16(4):271-7.

Sari Pediatri 2014;16(4):236-40.

Sari Pediatri 2014;16(3):215-20

Sari Pediatri 2015;16(6):441-6

Sari Pediatri 2014;16(1):53-6.

Sari Pediatri 2014;16(2):86-90.

Sari Pediatri 2015;16(6):434-40

Sari Pediatri 2014;16(4):254-9.

Sari Pediatri 2014;16(2):71-8.

Sari Pediatri 2015;16(5):356-64

Sari Pediatri 2014;16(2):115-20

Sari Pediatri 2014;16(3):183-8

Sari Pediatri 2014;16(2):141-6

Sari Pediatri 2015;16(6):409-15

Sari Pediatri 2014;16(2):71-8.

Sari Pediatri 2015;16(5):307-14

Sari Pediatri 2015;16(6):375-8.

Sari Pediatri 2015;16(5):330-6

Sari Pediatri 2015;16(6):421-6

Sari Pediatri 2015;16(5):330-6

Sari Pediatri 2014;16(4):241-7.

Sari Pediatri 2014;16(3):173-7

Sari Pediatri 2014;16(1):17-21

Sari Pediatri 2015;16(5):351-5

Sari Pediatri 2014;16(2):136-42. Sari Pediatri 2014;16(1):64-70. Sari Pediatri 2015;16(6):379-84 Sari Pediatri 2014;16(2):79-85. Sari Pediatri 2014;16(1):47-52.

Sari Pediatri 2015;16(5):347-50 Sari Pediatri 2015;16(6):397-402

Sari Pediatri 2014;16(4):254-9. Sari Pediatri 2015;16(5):307-14 Sari Pediatri 2015;16(5):351-5 Sari Pediatri 2014;16(4):241-7. Sari Pediatri2014;16(4):271-7. Sari Pediatri 2014;16(4):236-40. Sari Pediatri 2014;16(3):215-20 Sari Pediatri 2014;16(3):157-60 